\title{
LIBERDADE DE EXPRESSÃO E O PROCESSO DEMOCRÁTICO NA SOCIEDADE DA INFORMAÇÃO
}

\author{
FREEDOM OF EXPRESSION AND THE DEMOCRATIC \\ PROCESS IN THE INFORMATION SOCIETY
}

\author{
CAIO SPERANDÉO DE MACEDO ${ }^{1}$
}

\begin{abstract}
RESUMO: Analisa-se a liberdade de expressão e a de livre manifestação do pensamento como alternativas de comportamento do cidadão e como liberdades negativas que exigem abstenção por parte do Estado com o objetivo de esclarecer o conteúdo axiológico hodierno destes direitos fundamentais de primeira geração, bem como seus limites e implicações para a sociedade da informação e, neste contexto, sua ligação com o exercício da cidadania, destacando a tolerância como elemento propulsor do desenvolvimento dialético de uma sociedade democrática. PALAVRAS-CHAVE: Liberdade de Expressão; Livre Manifestação do Pensamento; Sociedade da Informação; Democracia; Tolerância.
\end{abstract}

ABSTRACT: An analysis of the freedom of expression and of the freedom of thought understood as a citizen behavior alternative and as negative liberties that require abstention by the State in order to clarify today's axiological content of these fundamental rights of first generation, as well as its limits and implications for the information society and in this context, its connection with the exercise of citizenship, highlighting tolerance as propellant element of the dialectical development of a democratic society.

KEYWORDS: Freedom of Expression; Freedom of Thought; The Information Society; Democracy; Tolerance.

SUMÁRIO: Introdução; 1. Liberdade como Alternativa de Comportamento; 2. Conteúdo da Liberdade de Expressão e Manifestação de Pensamento; 3. Limites à Liberdade de Expressão e da Manifestação do Pensamento; 4. É Possível Proibir a Liberdade de Expressão de Ideias e Opiniões?; 5. Liberdade de Expressão e da Manifestação do Pensamento na Sociedade da Informação; 6 . Liberdade de Expressão e Cidadania na Sociedade da Informação; 7. A Tolerância como Meio de Resguardar a Liberdade de Expressão e de Manifestação do Pensamento na Sociedade da Informação; Conclusão; Referências.

Artigo recebido em 16.04.2015. Pareceres emitidos em 18.05.2015, 18.08.2015 e 20.08.2015. Artigo aceito para publicação em 30.10.2015.

${ }^{1}$ Doutor em Filosofia do Direito. Mestre em Direito Constitucional e Graduado em Direito pela Pontifícia Universidade Católica de São Paulo (PUC-SP). Professor da Graduação e do Programa de Mestrado em Direito da Sociedade da Informação no Centro Universitário das Faculdades Metropolitanas Unidas - FMU/SP. Advogado. caio.csm@terra.com.br 
CONTENTS: Introduction; 1. Freedom as Behavioral Alternative; 2. Content of Freedom of Expression and Manifestation of Thought; 3. Restrictions on the Freedom of Speech and Expression of Thought; 4. Can you Prohibit the Free Expression of Ideas and Opinions?; 5. Freedom of Expression and the Expression of Thought in the Information Society; 6. Freedom of Expression and Citizenship in the Information Society; 7. The Tolerance as a Means of Protecting Freedom of Expression and Freedom of Thought in the Information Society; Conclusion; References.

\section{INTRODUÇÃO}

A liberdade de expressão e de livre manifestação do pensamento, enquanto direitos fundamentais de primeira geração, compreendidas como princípios constitucionais conformadores da Constituição Federal de 1988, por estabelecer ligação ontológica indelével com o desenvolvimento da personalidade humana, revelam-se imprescindíveis ao processo democrático, mormente na sociedade da informação diante do ilimitado fluxo de comunicação que trafega no espaço digital trazendo consigo a intersubjetividade, o compartilhamento de ideias, debates e o exercício do contraditório em torno de direitos e valores candentes na sociedade. Assim, em decorrência da renovação do domínio público Arendtiano ${ }^{2}$, contido especialmente nas mídias digitais $^{3}$ e como sinal dos tempos, a liberdade de expressão (de atividade intelectual, artística, científica e de comunicação) e de livre manifestação do pensamento assumem amplitude inaudita e devem ser analisadas de forma dinâmica e com elevado grau de tolerância a fim de que essas liberdades paradigmáticas não sejam tolhidas em prejuízo da evolução e amadurecimento da democracia.

Pode-se dizer, portanto, que a liberdade de expressão (art. 50, inciso IX, C.F), de livre manifestação do pensamento (art. $5^{\circ}$, inciso IV, C.F) e de comunicação social (art. 220 C.F) conjugadas se colocam funcionalmente como meio de preservação do desenvolvimento democrático na sociedade da informação, do azo que a tecnologia disponível permitiu criar canal privilegiado e acessível a um número exponencial de pessoas e ainda bastante livre para

\footnotetext{
${ }^{2}$ A Pluralidade humana, condição básica da ação e do discurso, tem o duplo aspecto da igualdade e da distinção. Se não fossem iguais, os homens não poderiam compreender uns aos outros e os que vieram antes deles, nem fazer planos para o futuro nem prever as necessidades daqueles que virão depois deles. Se não fossem distintos, sendo cada ser humano distinto de qualquer outro que é, foi ou será, não precisariam do discurso nem da ação para se fazerem compreender. [...] Só o homem, porém, é capaz de exprimir essa distinção e distinguir-se, e só ele é capaz de comunicar a si próprio e não apenas comunicar alguma coisa - como sede, fome, afeto, hostilidade ou medo. No homem, a alteridade, que ele partilha com tudo o que existe e a distinção, que ele partilha com tudo o que vive, tornam-se unicidade e a pluralidade humana é a paradoxal pluralidade de seres únicos. ARENDT, Hannah. A Condição Humana. 11. ed., revista. Tradução Roberto Raposo, Rio de Janeiro: Forense Universitária, 2010. p. 219-220.

${ }^{3}$ As conquistas tecnológicas estabeleceram novos paradigmas comportamentais e uma série de mudanças sociais e culturais comunicativas observadas nas mídias sociais interligadas pela rede internacional computadores (internet), notadamente em decorrência da disponibilidade de amplo acesso ao fluxo de transmissão de conhecimentos e informações que trafegam no espaço cibernético de forma instantânea e remotamente para qualquer lugar do mundo.
} 
a parla, o questionamento e a discussão da diversidade de valores em conflito na sociedade.

Concernente à condução da pesquisa, a metodologia científica adotada se concentra na revisão de bibliografia especializada sobre o tema e demais fontes referidas ao longo do texto abordando o conjunto das características comunicativas da sociedade da informação que influenciam particularmente como a liberdade de expressão e da livre manifestação do pensamento se desenvolvem no ambiente eletrônico e tem por objetivo demonstrar que a ampla liberdade de acesso e a interação conferida pelas mídias digitais são indispensáveis para o engrandecimento dessas liberdades para o tempo que vivemos. Cabe esclarecer ainda que se optou por valorizar a perspectiva sociológica e global do tema, donde não abordaremos a legislação infraconstitucional pátria ${ }^{4}$. Neste contexto, analisar o conteúdo axiológico dos dispositivos constitucionais que cuidam do tema e cuja importância é extreme de dúvidas para a sociedade, bem como ressaltar com esteio predominante na obra de autores como Manuel Castells e Gustavo Cardoso e corroborado por informações jornalísticas necessárias para estabelecer o suporte fático, que a lógica de funcionamento da sociedade da informação, a amplitude e alcance do fluxo de comunicação que trafega na via digital impõem uma análise da liberdade de expressão e de livre manifestação do pensamento sob uma perspectiva sociológica; aponta para a necessidade de o Estado dimensionar sua intervenção levando em conta o franco desenvolvimento de comunicação horizontal, intersubjetiva e socializante que os cidadãos vêm experimentando a partir do exercício dessas liberdades mediadas pelas redes digitais nas democracias contemporâneas. Em séquito, referendar que a atuação do Estado em seu papel regulador no tocante às manifestações volitivas, veiculadas através das mídias digitais, deve ser diminuta: regulamentar apenas os conteúdos tidos por estritamente necessários (por exemplo, nos casos de pedofilia; de conteúdos odiosos; racistas, ligados à privacidade; aos aspectos econômicos e de segurança, a criptografia ${ }^{5}$, acesso etc.), pois uma intervenção restritiva (com nuances de censura) não surtirá efeitos saneadores por contrariar a natureza libertária e a organização difusa da própria rede; elementos indispensáveis ao desenvolvimento da internet.

Ao final, reconhecer que estamos perante uma realidade social e cultural em transformação neste início de século XXI, que as redes impõem uma

\footnotetext{
${ }^{4}$ No Brasil, houve a recente publicação da Lei 12.965/2013, que ficou conhecida como o Marco Civil da Internet, que em linhas gerais organiza o tema em 3 grandes eixos; neutralidade da rede; liberdade de expressão e privacidade.

${ }^{5}$ A criptografia ou encriptação é um meio para melhorar a segurança de uma mensagem ou ficheiro através da codificação dos conteúdos, de modo a que só possam ser lidos por quem tenha a chave de encriptação correcta para os descodificar. Por exemplo, se comprar algo num Web site, as informações da transação (tais como endereço, número de telefone e número de cartão de crédito) são geralmente encriptadas para que se mantenham seguras. Utilize a encriptação quando pretender um nível de protecção elevado para as informações. Disponível em: <http://windows. microsoft.com/pt-pt/windows/what-is-encryption\#1TC=windows-7>. Acesso em: 06 abr. 2015.
} 
reconfiguração do papel do Estado e na forma peculiar de intervir no meio digital a qual deverá se voltar para resguardar a amplitude da liberdade de expressão e de manifestação do pensamento experimentadas junto aos canais cibernéticos e valorizar maior participação dos cidadãos na construção de novos contornos para a democracia contemporânea.

\section{LIBERDADE COMO ALTERNATIVA DE COMPORTAMENTO}

Posso não concordar com o que você diz, mas defenderei até a morte o direito de dizê-Io ${ }^{6}$.

Para J. J. Gomes Canotilho ${ }^{7}$, em referência à Constituição portuguesa de 1976 e plenamente aplicável à Constituição Federal brasileira de 1988, ou a qualquer outra de cunho democrático, as liberdades podem ser entendidas como posições fundamentais subjetivas, pois:

As liberdades (liberdade de expressão, liberdade de informação, liberdade de consciência, religião e culto, liberdade de criação cultural, liberdade de associação) costumam ser caracterizadas como posições fundamentais subjetivas de natureza defensiva. Neste sentido, as liberdades identificam-se com direitos a ações negativas; seriam abwehrrechte (direitos de defesa). Resulta logo do enunciado constitucional que, distinguindo-se entre 'direitos, liberdades e garantias', tem de haver algum traço específico, típico das posições subjectivas identificadas como liberdades. Esse traço específico é o da alternativa de comportamentos, ou seja, a possibilidade de escolha de um comportamento. Assim, como vimos, o direito à vida é um direito (de natureza defensiva perante o Estado), mas não é uma liberdade (o titular não pode escolher entre 'viver ou morrer'). A componente negativa das liberdades constitui também uma dimensão fundamental (ex. ter ou não ter religião, fazer ou não fazer parte de uma associação, escolher uma ou outra profissão).

Assim, as referidas liberdades são consideradas como negativas (de expressão do pensamento, de informação e de comunicação etc.), pois exigem que o Governo se abstenha de cercear essas manifestações sociais; por outro lado consiste em conferir direito ao livre-arbítrio aos cidadãos de fazer suas escolhas e de se comunicar livremente; ou ainda permanecer silente e não fazer escolha nenhuma ${ }^{8}$. Robert Alexy ${ }^{9}$ complementa com relação à

\footnotetext{
${ }^{6}$ Frase atribuída ao iluminista Voltaire (François-Marie Arouet). Disponível em: <pensador.uol. com.br/posso_nao_concordar_com_o_que_dizes/>. Acesso em: 25 mar. 2015.

${ }^{7}$ CANOTILHO. J. J. Gomes. Direito Constitucional e Teoria da Constituição. 4. ed., Coimbra: Ed. Almedina, p. 1245-1246.

${ }^{8}$ Acrescente-se que, na liberdade de manifestação do pensamento, se inclui, também, o direito de tê-lo em segredo, isto é, o direito de não manifestá-lo, recolhendo-o na esfera íntima do indivíduo. SILVA, José Afonso da. Curso de Direito Constitucional Positivo. 9. ed., São Paulo: Malheiros, 1994, p. 222.

${ }_{9}$ ALEXY, Robert. Teoria dos Direitos Fundamentais. Tradução Virgílio Afonso da Silva. 2. ed., São Paulo: Malheiros, 2014, p. 222.
} 
classificação das liberdades que, enquanto a positiva o objeto da liberdade é uma única ação, as negativas se caracterizam por comportar alternativas de ação ${ }^{10}$. J. J. Gomes Canotilho faz alusão à teoria democrático-funcional dos direitos fundamentais para expor a ideia de ligação direta entre esses direitos, como "exempli gratia" a liberdade de expressão, manifestação do pensamento e de informação, com o desenvolvimento do próprio processo políticodemocrático, ao sustentar que:

[...] (a) os direitos são concedidos aos cidadãos para serem exercidos como membros de uma comunidade e no interesse público; (b) a liberdade não é a liberdade pura e simples mas a liberdade como meio de prossecução e segurança do processo democrático, pelo que se torna patente seu caráter funcional; (c) se o conteúdo e alcance dos direitos fundamentais se encontra funcionalmente condicionado, também se compreende que o respectivo exercício não esteja na completa disponibilidade dos seus titulares: o direito é simultaneamente um dever; (d) dado o caracter marcadamente funcional dos direitos, aos poderes públicos é reconhecido o direito de intervenção conformadora do uso dos direitos fundamentais. Esta teoria parte da ideia de cidadão activo, com direitos fundamentais postos ao serviço do princípio democrático. [...] Alguns pontos de partida das actuais doutrinas incidentes sobre a razão comunicativa, a liberdade política e a liberdade de expressão parecem estar próximas desta teoria democrática-funcional dos direitos. ${ }^{11}$

Portanto, pela teoria democrático-funcional o franco exercício destas liberdades complementares (de expressão, de opinião, de informação, de comunicação, etc.) pelos cidadãos e através dos meios de comunicação tradicionais e digitais tem o condão de sustentar permanentemente a discussão e desenvolvimento do processo democrático em prol do interesse da sociedade. Celso Ribeiro Bastos ${ }^{12}$ reforça a importância destas liberdades classificadas como direito fundamental de primeira geração (ou dimensão) ao recordar que a própria "Declaração de Direitos do Homem de 1789", em seu art. 11 reconhece que: "A livre comunicação dos pensamentos e das opiniões é um dos direitos mais preciosos do homem; todo cidadão pode, pois falar, escrever, exprimir-se livremente, sujeito a responder pelo abuso desta liberdade nos casos determinados na lei". Por corolário, tais liberdades de expressão e de livre manifestação do pensamento estão intimamente ligadas aos meios de comunicação em geral, da imprensa e das telecomunicações (ou de antena) que lhes são complementares, nisso incluídas as demais mídias que trafegam pela rede mundial de computadores eletronicamente (internet); assim, estes últimos aparecem como liberdades secundárias que decorrem das liberdades primárias de expressão e da manifestação do pensamento.

\footnotetext{
${ }^{10}$ ALEXY, Robert. Op. cit., p. 222.

${ }_{11}^{11}$ CANOTILHO. J. J. Gomes. Op. cit., p. 1384.

12 BASTOS, Celso Ribeiro. Curso de Direito Constitucional. São Paulo: Celso Bastos Editora, 2002, p. 329.
} 
Referido autor ${ }^{13}$, examinando o sentido da liberdade de opinião complementa sua análise no sentido de que ela apresenta dois aspectos quanto ao seu valor: "o primeiro chamado 'valor da indiferença'. Neste caso, a liberdade em pauta significa que a opinião não deve ser tomada em consideração. Confunde-se, nesta hipótese, com a noção de neutralidade, como ocorre do ângulo religioso com o Estado laico". Complementa o seu raciocínio afirmando que já a liberdade de opinião, ao contrário, "pode significar que o fato de ter-se uma opinião implica o seu respeito. A liberdade tem aqui um valor de exigência".

Assim, a liberdade de expressão e de manifestação do pensamento e opinião exige que sejam analisados seus predicados sob duas vertentes: A primeira (a da indiferença), para reconhecer e aceitar que há uma ampla liberdade do cidadão em ter qualquer opinião sobre determinado assunto ou simplesmente não ter; a segunda, é que uma vez manifestada opinião pelo cidadão, impõem-se à sociedade e ao Estado respeitar e levar em consideração a assertiva ventilada para o fortalecimento do pluralismo democrático. Também defende Paulo Gustavo Gonet Branco ${ }^{14}$ a importância destes direitos para o desenvolvimento da sociedade democrática ao esclarecer que:

A plenitude da formação da personalidade depende de que se disponha de meios para conhecer a realidade e as suas interpretações, e isso como pressuposto mesmo para que se possa participar de debates e para que se tomem decisões relevantes. O argumento humanista, assim, acentua a liberdade de expressão como corolário da dignidade humana. $\mathrm{O}$ argumento democrático acentua que 'o autogoverno postula um discurso político protegido das interferências do poder'. A liberdade de expressão é, então, enaltecida como instrumento para o funcionamento e preservação do sistema democrático (o pluralismo de opiniões é vital para a formação de vontade livre).

Ademais, tem a acrescentar Paulo Gustavo Gonet Branco ${ }^{15}$ que a personalidade humana se constitui no contato com outras pessoas, do azo que a liberdade de comunicação é ínsita à própria sociabilidade do ser humano, consoante o conceito de zoon politikón de Aristóteles ${ }^{16}$ : “... o homem é naturalmente um animal político, destinado a viver em sociedade". Logo, essas liberdades comunicativas têm por escopo conferir elasticidade para a reflexão constante da sociedade; em outras palavras, possibilitam o intercâmbio e o debate de ideias como elementos naturais de formação da livre convicção da opinião pública e da personalidade humana ao propiciar alternativas para

\footnotetext{
${ }^{13}$ BASTOS, Celso Ribeiro. Op. cit., p. 331.

${ }^{14}$ BRANCO, Paulo Gustavo Gonet; MENDES, Gilmar Ferreira. Curso de Direito Constitucional. 8. ed., ver. atual. São Paulo: Saraiva, 2013, p. 264.

${ }^{15}$ Ibid.

${ }^{16}$ ARISTÓTELES. A Política. 1. ed., Tradução Nestor Silveira. São Paulo: Folha de São Paulo, 2010, p. 13.
} 
compreender a realidade e a diversidade de suas interpretações, influenciando comportamentos (iguais ou diversos do nosso, que precisam ser respeitados).

\section{CONTEÚDO DA LIBERDADE DE EXPRESSÃO E MANIFESTAÇÃO DE PENSAMENTO}

Quanto ao conteúdo que encerra a liberdade de expressão e a de manifestação do pensamento, José Afonso da Silva ${ }^{17}$ sustenta que a liberdade de expressão intelectual, artística, científica e comunicacional assegurada pela Constituição Federal no inciso IX, do art. $5^{\circ}$ refere-se à liberdade de exteriorização dessas atividades, as quais correspondem a formas de difusão e manifestação do pensamento, " tomado esse termo em sentido abrangente dos sentimentos e dos conhecimentos intelectuais, conceptuais e intuitivos ${ }^{18}$." Continua afirmando que a liberdade de manifestação do pensamento trata-se de um dos aspectos externos da liberdade de opinião e que isso consta tanto do inciso IV do art. $5^{\circ}$, quanto do art. 220 que dispõe que "a manifestação do pensamento, a criação, a expressão e a informação, sob qualquer forma ou veículo, não sofrerão qualquer restrição, observado o disposto nesta Constituição, sendo 'vedada toda e qualquer censura política, ideológica e artística"19 .

A liberdade de manifestação do pensamento tem seus ônus, tal como o de o manifestante identificar-se, assumir claramente a autoria do produto do pensamento manifestado, para, sendo o caso, responder por eventuais danos a terceiros. Daí por que a Constituição veda o anonimato. A manifestação do pensamento não raro atinge situações jurídicas de outras pessoas, a que corre o direito, também fundamental, de resposta (art. $\left.5^{\circ}, \mathrm{V}\right) .^{20}$

Assim, a liberdade de expressão e seus desdobramentos bem como a de manifestação do pensamento se assentam em contornos amplos em uma democracia pluralista e tem por foco garantir a tutela de outros direitos fundamentais que envolvam a comunicação como opiniões, debates, convicções, comentários ou julgamento sobre qualquer assunto ou pessoa, envolvendo interesse público, ou não, quer sejam importantes ou não. Adverte, contudo, Paulo Gustavo Gonet $B$ ranco $^{21}$ que a liberdade de expressão não dá guarida a violência e tem por premissa, em decorrência de seu caráter negativo, que o Estado se abstenha de exercer qualquer censura. Vez que não é papel do Estado estabelecer qual opinião merece repulsa e quais devem ser aceitas; esse discernimento é tarefa particular e individual de cidadãos cônscios e livres.

\footnotetext{
${ }^{17}$ SILVA, José Afonso da. Comentário Contextual à Constituição. 5. ed., São Paulo: Malheiros Editores, 2007, p. 90-91, 99.

${ }^{18}$ Ibid., p. 99.

${ }^{19}$ Ibid.

${ }^{20}$ Ibid., p. 91.

${ }^{21}$ BRANCO, Paulo Gustavo Gonet. Op. cit., p. 264.
} 
Não se olvide que em contrapartida à proibição da censura (prévia) por parte do Estado, o cidadão permanecerá responsável civil e penalmente por suas ideias e opiniões que venham a transbordar a tolerância da sociedade e os limites estabelecidos juridicamente. Tanto que nossa Lei Maior assegura a todos o direito de resposta (art. $5^{\circ}, \mathrm{V}, \mathrm{C} . \mathrm{F}$ ) proporcional ao agravo para retratação da imagem e honra do indivíduo ofendido, sem prejuízo de ser indenizado por danos morais e materiais causados pelo ofensor.

\section{LIMITES À LIBERDADE DE EXPRESSÃO E DA MANIFESTAÇÃO DO PENSAMENTO}

Outrossim, Celso Ribeiro Bastos ${ }^{22}$ destaca que o texto constitucional de 1988 foi feliz ao coibir a expressão do pensamento anônimo, a fim de possibilitar a responsabilização do eventual ofensor. Prossegue afirmando que o direito de resposta constitucionalmente assegurado não se aplica apenas em casos de lesões provenientes dos meios de comunicação. "É inerente ao processo de informação e, portanto, deverá ser assegurado em quaisquer modalidades sob as quais esta se dá. Com essa amplitude, ele é não apenas exercitável na imprensa falada, escrita ou televisionada, mas inclusive diretamente, se for o caso, como uma assembleia por exemplo" ${ }^{, 23}$.

Ademais, o artigo $220^{24}$ da Carta de 1988 complementa para esclarecer que não haverá restrição ao direito de manifestação do pensamento, criação expressão e informação, dispondo no $\S 1^{\circ}$ que 'nenhuma lei conterá dispositivo que possa constituir embaraço à plena liberdade de informação jornalística em qualquer veículo de comunicação social', ressalvando que será "observado o disposto no art. $5^{\circ}$, IV , V, X, XIII, e XIV"25. Logo, em linhas gerais, a liberdade de expressão encontra seus limites para proibir o anonimato, para impor direito de resposta, indenizar por danos morais e patrimoniais e à imagem causados, para preservar a intimidade, a vida privada, a honra e a imagem das pessoas, e para que se assegure a todos o direito de acesso à informação.

\footnotetext{
${ }^{22}$ BASTOS, Celso Ribeiro. Op. cit., p. 333-334.

${ }^{23}$ Ibid.

${ }^{24}$ Art. 220. A manifestação do pensamento, a criação, a expressão e a informação, sob qualquer forma, processo ou veículo não sofrerão qualquer restrição, observado o disposto nesta Constituição. $\S 1^{\circ}$ - Nenhuma lei conterá dispositivo que possa constituir embaraço à plena liberdade de informação jornalística em qualquer veículo de comunicação social, observado o disposto no art. $5^{\circ}, I V, V, X, X I I I$ e XIV. § $2^{\circ}$ - É vedada toda e qualquer censura de natureza política, deológica e artística.

${ }^{25}$ Art. $5^{\circ}$ Todos são iguais perante a lei, sem distinção de qualquer natureza, garantindo-se aos brasileiros e aos estrangeiros residentes no País a inviolabilidade do direito à vida, à liberdade, à igualdade, à segurança e à propriedade, nos termos seguintes: [...]; IV - é livre a manifestação do pensamento, sendo vedado o anonimato; $\mathrm{V}$ - é assegurado o direito de resposta, proporcional ao agravo, além da indenização por dano material, moral ou à imagem; X - são invioláveis a intimidade, a vida privada, a honra e a imagem das pessoas, assegurado o direito à indenização pelo dano material ou moral decorrente de sua violação; XIII - é livre o exercício de qualquer trabalho, ofício ou profissão, atendidas as qualificações profissionais que a lei estabelecer; XIV - é assegurado a todos o acesso à informação e resguardado o sigilo da fonte, quando necessário ao exercício profissional.
} 
Além das restrições acima referidas outros valores constitucionais podem entrar em conflito com a liberdade de expressão exigindo-se conforme o caso concreto o balanceamento ou ponderação entre os valores fundamentais envolvidos a fim de decidir qual princípio deverá preponderar. Paulo Gustavo Gonet Branco ${ }^{26}$ faz referência à jurisprudência norte-americana para destacar que referida liberdade está também sujeita a sofrer outras restrições de ordem prática vivenciadas pelos Estados contemporâneos como a repulsa a manifestações que exortem a violência ou tentativa de instaurar clima de pânico na sociedade. $O$ autor também destaca o contexto que a mensagem ou discurso é proferido e veiculado a fim de se discernir entre abusos da imprensa e a legítima liberdade de imprensa e comunicação socializante:

Quando se busca situar uma hipótese no domínio normativo da garantia constitucional da liberdade de expressão, há de se atentar, igualmente, para o contexto em que o discurso é proferido. Isso é crucial para que se concilie a legislação repressiva de abusos da imprensa com a própria liberdade de imprensa, tendo em vista os limites a que a liberdade de expressão se submete numa sociedade democrática. O Supremo Tribunal Federal tem assinalado, por exemplo, que declarações inadmissíveis em outras situações tendem a ser toleradas 'no contexto político em que a linguagem contundente se insere no fervor da refrega eleitoral. ${ }^{27}$

Portanto, além do que preveem as hipóteses Constitucionais o contexto em que foi proferida a manifestação deverá ser sopesado com outros princípios constitucionais colidentes, corroborado pela análise do caso concreto específico, para se aquilatar com maior precisão se tal manifestação encontra respaldo constitucional. Paulo Gustavo Gonet Branco esclarece complementarmente que também nos casos de "charge", caricaturas ou ilustrações humorísticas deve ser analisada a compatibilidade com o respeito à honra de terceiros quanto aos limites da liberdade de expressão em conjunto com a liberdade de imprensa, embora aduza que tal tipo de humor venha sendo de certa forma aceita pela sociedade. Lembra que a charge política que em geral não costuma agradar ao retratado pode suscitar questões interessantes devendo haver, no entanto, ponderação entre liberdade de expressão e proteção da honra. "Tem sido, entretanto, admitida, em princípio, como lícita manifestação da liberdade de expressão. Ao intuito de crítica pelo riso, é ínsita a forma jocosa. A latitude de tolerância, aqui, depende, novamente, do sentimento geral da sociedade com relação a crítica, às vezes mordaz, que peculiariza a charge". ${ }^{28}$

Como observação à relativa tolerância da sociedade contemporânea com relação ao exercício da liberdade de expressão por meio de caricaturas humorísticas, impossível não fazer referência ao recente assassinato de

\footnotetext{
${ }^{26}$ BRANCO, Paulo Gustavo Gonet. Op. cit., p. 273-274.

${ }^{27}$ Ibid.

${ }^{28}$ Ibid., p. 277.
} 
doze pessoas, destes, dez entre jornalistas e cartunistas da tradicional publicação (semanário impresso) satírica "Charlie Hebdo" perpetrada por extremistas islâmicos na França, em 7 de Janeiro de 2015, sob o pretexto de que determinada caricatura veiculada em capa da edição de referida data teria ofendido o profeta Maomé ${ }^{29}$ e; portanto, profanado sua crença ${ }^{30}{ }^{31}$.

${ }^{29}$ Disponível em: <http://www.dn.pt/inicio/globo/interior.aspx?content_id=4327721>. Acesso em: 09 mar. 2015.

${ }^{30}$ Para Leonardo Boff, em texto publicado e 10.01.2015: [...] A França tem 6,2 milhões de muçulmanos. São, na maioria, imigrantes das ex-colônias francesas. Esses muçulmanos não estão inseridos igualmente na sociedade francesa. A grande maioria é pobre, legada à condição de "cidadão de segunda classe", vítimas de preconceitos e exclusões. Após os atentados do World Trade Center, a situação piorou. Alguns chamam os cartunistas mortos de "heróis" ou de os "gigantes do humor politicamente incorreto", outros muitos os chamam de "mártires da liberdade de expressão". Vou colocar na conta do momento, da emoção. As charges polêmicas do Charlie Hebdo, como os comentários políticos de colunistas da Veja, são de péssimo gosto, mas isso não está em questão. O fato é que elas são perigosas, criminosas até, por dois motivos: o primeiro é a intolerância. Na religião muçulmana, há um princípio que diz que o Profeta Maomé não pode ser retratado, de forma alguma. Esse é um preceito central da crença Islâmica, e desrespeitar isso desrespeita todos os muçulmanos. Fazendo um paralelo, é como se um pastor evangélico chutasse a imagem de Nossa Senhora para atacar os católicos.(...) Mas existe outro problema, ainda mais grave. A maneira como o jornal retratava os muçulmanos era sempre ofensiva. Os adeptos do Islã sempre estavam caracterizados por suas roupas típicas, e sempre portando armas ou fazendo alusões à violência, com trocadilhos infames com "matar" e "explodir". Alguns argumentam que o alvo era somente "os indivíduos radicais", mas a partir do momento que somente esses indivíduos são mostrados, cria-se uma generalização. Disponível em <https://leonardoboff.wordpress.com/2015/01/10/eu-nao-sou-charlie-je-ne-suis-pas-charlie/>. Acesso em: 10 mar. 2015.

${ }^{31}$ Como contraponto, texto do jornalista Leigh Philips de 15/01/2015: Perdida na tradução: Charlie Hebdo, liberdade de expressão e a esquerda monolíngue. Nas 48 horas após o massacre de Paris, muitos ativistas e acadêmicos de esquerda anglófonos apressaram-se em zombar das demonstrações públicas de solidariedade aos cartunistas e jornalistas assassinados do jornal satírico francês Charlie Hebdo e criticaram as vigílias, as manifestações e os cartuns de outros artistas como se estes estivessem aliando-se a racistas. É claro que o assassinato de jornalistas é uma coisa ruim, assim prossegue o argumento, mas, vamos lá, Charlie Hebdo é "uma publicação racista". Então o que você espera? É a implícita conclusão da culpabilização da vítima. [...] Os últimos dias têm sido uma humilhação para a esquerda anglófona, mostrando ao mundo quão pobre é a nossa capacidade de tradução hoje em dia, quando tantas pessoas publicaram nas redes sociais os cartuns que encontraram ao vasculhar o Google Imagens, usando-os como evidência do "racismo óbvio" do Charlie Hebdo, apenas para serem informadas por um francês fluente em inglês que, quando traduzidos e colocados no contexto, estes cartuns, na verdade, são explicitamente ou antirracistas ou um escárnio a racistas e fascistas. O melhor exemplo aqui é o cartum amplamente compartilhado do editor assassinado Stéphane Charbonnier, conhecido como Charb, da cabeça de uma mulher negra em um corpo de macaco abaixo da frase "Rassemblement Bleu Raciste" (Agrupamento Azul Racista). Os franceses estão cientes de que a mulher no cartum é a Ministra da Justiça, Christiane Taubira, e que a flâmula vermelha, branca e azul no cartum é a logo da Frente Nacional, que tinha recentemente caído em maus lençóis por publicar uma foto de um bebê macaco com as palavras "Aos 18 meses" próxima a um retrato de Taubira com a palavra "Agora". O slogan da Frente Nacional é Rassemblement Bleu Marine (Agrupamento Azul Marinho), um jogo de palavras com o nome da sua líder, Marine Le Pen. É óbvio para qualquer francês familiarizado com o contexto político que o cartum está zombando do racismo da Frente Nacional e, de fato, a própria Taubira, na sequência do massacre, defendeu repetidamente o Charlie Hebdo. Disponível em: <http://passapalavra.info/2015/01/101964>, Acesso em: 05 mar. 2015. 
Fora de dúvida que houve uma desproporção entre a publicação da charge jocosa e gosto duvidoso (característica desta publicação francesa, inclusive com outras confissões religiosas), mas que integra o exercício da liberdade de expressão e a força bruta assassina perpetrada pelos radicais muçulmanos (cidadãos franceses) que têm democraticamente o direito de demonstrar seu inconformismo pelos métodos concebidos pelo Estado de direito, nisso incluído protestos públicos, mobilizações de pessoas e entidades civis ou organismos internacionais em defesa de sua fé, inclusive acionar o sistema Judiciário. Entrementes, mesmo com relação ao lamentável episódio de intolerância acima narrado, Ian Mcewan ${ }^{32}$ traz a dimensão desta liberdade fundamental ao sustentar que se trataria da mesma liberdade tanto a dos jornalistas do referido semanário de criarem sua sátira como a dos muçulmanos da França de seguirem sua religião e de expressar seus pontos de vista abertamente. Segundo lan Mcewan não é possível aos devotos ter as duas coisas. "A livre expressão é dura, é barulhenta e, às vezes, fere, mas quando tantas visões de mundo precisam conviver lado a lado, a única alternativa à livre expressão é a intimidação, a violência e o conflito acirrado entre comunidades".

Prossegue Ian Mcewan para esclarecer que embora a liberdade de expressão não seja um valor absoluto ela é a gênese das outras e, quando tolhida, todas as demais liberdades (de dar e receber informações, de formular perguntas incômodas, de realizar pesquisas acadêmicas, de praticar a crítica, a fantasia, a sátira, o intercâmbio de ideias etc) restam cerceadas e inclusive a própria democracia se torna apenas um simulacro.

Acima de tudo, cabe referendar que a liberdade de expressão é um direito negativo exigindo como regra uma abstenção por parte do Estado e dos Governos. Enquanto princípio norteador da democracia deve ser analisado com elevado grau de tolerância diante da sua vital importância para a livre reflexão da sociedade; ao possibilitar o intercambio e debate de ideias como elementos naturais de formação da personalidade humana, como forma de reconhecer novos direitos, para compreender a realidade e suas interpretações. Mormente, no caso em comento, pois a liberdade de crença religiosa (art. $\left.5^{\circ}, \mathrm{VI}\right)$ impõe aos cidadãos fomentar o respeito a todos os credos, suas liturgias e símbolos; e a liberdade de expressão, do qual aquela é oriunda, assegura o direito de manifestação dos cidadãos inclusive com relação a estes mesmos credos, liturgias e símbolos dentro de uma atmosfera de tolerância e de convivência com o diverso. Eventuais abusos e excessos devem ser compreendidos no âmbito de um Estado democrático de direito, no contexto do caso concreto e da legislação competente que rege determinada sociedade, cabendo à Justiça dirimir o conflito e responsabilizar a quem de direito.

\footnotetext{
32 MCEWAN, Ian. Liberdade de Expressão. Jornal Folha de São Paulo, Tendências/Debates. Tradução de Clara Allain, edição de 2 de janeiro de 2015.
} 


\section{4. É POSSÍVEL PROIBIR A LIBERDADE DE EXPRESSÃO DE IDEIAS E OPINIÕES?}

Não obstante o princípio constitucional da liberdade de expressão e de manifestação do pensamento estabelecer uma abstenção por parte do Estado a fim de não embaraçar seus exercícios, existem justificadas exceções para até mesmo proibir previamente sua veiculação. Embora não esteja em discussão a censura por parte de órgãos da administração pública em um país democrático, a questão reside em saber se o Judiciário pode proibir cautelarmente uma matéria jornalística em um caso concreto envolvendo conflito de direitos fundamentais como, por exemplo, a liberdade de informar "versus" a preservação de imagem. Em análise da redação normativa vislumbra-se que os dispositivos que cuidam do tema (art. $5^{\circ}$, IV, V, IX e art. 220 C.F, $\S 2^{\circ}$ ) são enfáticos em obstar qualquer censura ou exigir licença para se exercer a liberdade de manifestação. Assim, por essa vertente, a Constituição de 1988 teria optado por impingir sanção (civil e penal) posterior nos casos de transbordamento dos limites da liberdade de expressão. Contudo, conforme posição defendida por Gilmar Ferreira Mendes ${ }^{33}$ e outros, a interpretação constitucional impõe proteção preventiva em caso de outro princípio fundamental estiver na iminência de ser maculado. Pois, em suas palavras, "evidente que o constituinte não pretendeu assegurar apenas eventual direito de reparação ao eventual atingido", vez que a garantia da efetiva proteção jurisdicional (art. 50, XXXV) restaria letra morta "se a intervenção somente pudesse se dar após a configuração da lesão". Assim, outros valores igualmente protegidos pela Constituição como, por exemplo, a inviolabilidade da intimidade, da vida privada, a honra etc. (art. $5^{\circ}$, X, C.F) perderia seu conteúdo de "inviolável"; donde a eventual indenização posterior prevista na Carta de 1988 só tem aplicação remediadora quando não for possível obstar judicialmente a publicação da matéria lesiva à personalidade do ofendido.

Ao cuidar do tema Uadi Lammêgo Bulos ${ }^{34}$ esclarece que a liberdade de expressão do pensamento (intelectual, artística, científica e de comunicação) é própria do Estado Democrático de Direito não podendo estar sujeita a qualquer tipo de censura ou licença prévia. Ademais, cumpre ao Estado cuidar da moralidade e proibir a divulgação de notícias injuriosas, falsas e difamantes. "Um depoimento de agente formador de opinião, por exemplo, concitando o crime de racismo, deve ter a sua exibição proibida, pois a liberdade de expressão tem de conviver em harmonia com as demais garantias constitucionais, dentre elas a proibição do preconceito (CF, art. $\left.5^{\circ}, \mathrm{XLII}\right)^{335}$.

Como se depreende, consagra-se a máxima de que não existem direitos fundamentais absolutos cabendo ao magistrado nas hipóteses provocadas

\footnotetext{
${ }^{33}$ MENDES, Gilmar Ferreira. Direitos Fundamentais e Controle de Constitucionalidade. São Paulo: Celso Bastos Editor, 1998, p. 86.

${ }^{34}$ BULOS, Uadi Lammêgo. Direito Constitucional ao Alcance de Todos. 3. ed., São Paulo: Ed. Saraiva, 2011, p. 333.

${ }^{35}$ Ibid.
} 
exercer a ponderação entre princípios colidentes ao caso concreto para o deslinde da causa em exame. Este discernimento faz sentido, pois ao ter conhecimento de iminente publicação que macule sua honra ou privacidade o cidadão tem constitucionalmente reconhecido o direito de se socorrer ao Judiciário que, por sua vez, se entender pertinentes os argumentos invocados pode obstar preventivamente a publicação deletéria. Em um espectro que ressalta o equilíbrio que deve permear a relação entre liberdade de expressão e demais direitos fundamentais numa sociedade democrática, impõe-se observar que:

A liberdade de expressão é um direito fundamental, mas não é absoluto, e não pode ser usado para justificar a violência, a difamação, a calúnia, a subversão ou a obscenidade. As democracias consolidadas geralmente requerem um alto grau de ameaça para justificar a proibição da liberdade de expressão que possa incitar à violência, a caluniar a reputação de outros, a derrubar um governo constitucional ou a promover um comportamento licencioso. A maioria das democracias também proíbe a expressão que incita ao ódio racial ou étnico.

O desafio para uma democracia é o equilíbrio: defender a liberdade de expressão e de reunião e ao mesmo tempo impedir o discurso que incita à violência, à intimidação ou à subversão ${ }^{36}$.

Dessarte, pelo mesmo caminho deve ser interpretado o princípio da liberdade de expressão quando determinada publicação jornalística a título de informação e ainda que verdadeira infringir a intimidade de determinada pessoa. Já que a prova da verdade (factual) não pode servir como salvoconduto para macular a privacidade ou intimidade dos cidadãos. Na hipótese, devem ser ponderados os princípios em conflito para o caso concreto, notadamente quanto ao critério de interesse da coletividade a ser informada sobre a questão (art. $5^{\circ}, \mathrm{XIV}$ ).

\section{LIBERDADE DE EXPRESSÃO E DA MANIFESTAÇÃO DO PENSAMENTO NA SOCIEDADE DA INFORMAÇÃO}

Sustenta Javier Bustamante Donas ${ }^{37}$ que provavelmente a internet é a estrutura social mais democrática e participativa que as novas tecnologias da comunicação proporcionaram à sociedade ${ }^{38}$; aduz que o grande atrativo é sua natureza aberta e que os intentos para restringir o livre fluxo de informação assim como tentativas de limitar o que se pode falar pelo telefone - implicam

\footnotetext{
${ }^{36}$ Texto sobre princípios da democracia, liberdade de expressão, veiculado pela Embaixada dos Estados Unidos no Brasil. Disponível em: <http://www.embaixada-americana.org.br/democracia/ speech.htm>. Acesso em: 03 fev. 2015.

${ }^{37}$ DONAS, Javier Bustamante. Hacia la Cuarta Generación de Derechos Humanos: repensando la condición humana en la sociedad tecnológica, p. 4. Disponível em: <htttp://www.oei.es/revista/ numero1/Bustamante.htm>. Acesso em: 25 mar. 2015.

${ }^{38}$ Ibid.
} 
uma limitação onerosa e não razoável aos princípios da privacidade e da liberdade de expressão. No âmbito cibernético a liberdade de expressão não é apenas um dos direitos fundamentais, mas também uma condição de possibilidade para a defesa e desenvolvimento dos demais direitos ${ }^{39}$. Destaca o autor ainda que o fato de a internet ter se popularizado e se tornado uma infraestrutura técnica barata, horizontal e de âmbito global, faz com que a liberdade de expressão e todas as demais liberdades a ela associada devam ser aplicadas em toda a sua extensão nas atividades pessoais que se realizam na rede digital ${ }^{40}$.

No tocante à abertura da internet, Manuel Castells ${ }^{41}$ elucida que em sentido técnico é correto afirmar-se que os fluxos de informação que trafegam no meio digital podem interpretar a censura ou a interceptação como uma falha técnica e tendem a encontrar automaticamente um caminho de transmissão da mensagem. Por ser uma rede global com poder de processamento de informação e comunicação multimodal, a internet não distingue fronteiras e estabelece comunicação irrestrita entre todos os seus nós. $E$ conclui: "A única censura direta possível de internet é não estar na rede" ${ }^{\text {"42. }}$.

Nesse contexto, com a crescente popularização das novas tecnologias da comunicação ${ }^{43}$ ínsitas à sociedade da informação pode-se dizer que houve um engrandecimento do espaço da aparência ou de domínio público exercido pelos cidadãos, no sentido desenvolvido por Hannah Arendt ${ }^{44}$, com a franca utilização do canal digital socializante contido na rede mundial de computadores (Internet) para o exercício da liberdade de expressão, de manifestação do pensamento e, por corolário, de cidadania, como confirmam eventos da Primavera Árabe ${ }^{45}$.

\footnotetext{
${ }^{39}$ DONAS, Javier Bustamante. Op. cit., p. 5.

40 Ibid.
}

${ }^{41}$ CASTELLS, Manuel. Internet, Libertad y Sociedad: una perspectiva analítica. Por una nueva globalización. Polis, Revista Latinoamericana, n 4, 2003, p. 3. Disponível em: <http://polis.reveus. org/7145\#tocfrom1n1>. Acesso em: 27 mar. 2015.

42 Ibid.

${ }^{43}$ Pode-se compreender as novas tecnologias da informação como uma rede interligada digitalmente em escala planetária possibilitada pelas inovações tecnológicas como o microprocessador, a comunicabilidade por satélites, a comunicação mediada por computadores (internet) e a transmissão de dados via fibra ótica.

${ }^{44}$ ARENDT, Hannah. Op. cit., p. 275.

${ }^{45}$ Primavera Árabe, como é conhecida mundialmente, é uma onda revolucionária de manifestações e protestos que vêm ocorrendo no Oriente Médio e no Norte da África, desde 18 de dezembro de 2010. Até a data, tem havido revoluções na Tunísia e no Egito, uma guerra civil na Líbia e na Síria; também houve grandes protestos na Argélia, Bahrein, Djibuti, Iraque, Jordânia, Omã e lémen e protestos menores no Kuwait, Líbano, Mauritânia, Marrocos, Arábia Saudita, Sudão e Saara Ocidental. Os protestos têm compartilhado técnicas de resistência civil em campanhas sustentadas envolvendo greves, manifestações, passeatas e comícios, bem como o uso das mídias sociais, como Facebook, Twitter e Youtube, para organizar, comunicar e sensibilizar a população e a comunidade internacional em face de tentativas de repressão e censura na Internet por partes dos Estados. Disponível em: <http://pt.wikipedia.org/wiki/Primavera_\%C3\%81rabe>. Acesso em: 10 mar. 2015. 
Importante destacar que houve uma mudança qualitativa imposta pela dinâmica da via digital já que usuários ultrapassaram a categoria de meros receptores coletivos de conteúdo de comunicação de massa (rádio e tv); agora a interação comunicativa pode se dar de forma remota e em tempo real entre os usuários das mídias digitais e passa a alcançar intersubjetividade ao possibilitar a troca de opiniões, discussões e debates sobre a informação ou manifestação recebida pela rede mundial de computadores (internet) e influenciar a propagação da mensagem para demais usuários conectados. Esclarece Manuel Castells quanto à abrangência das redes digitais na sociedade contemporânea que a capacidade de inclusão de todas as expressões culturais é o que caracteriza o atual sistema comunicacional, que se baseia na integração em rede digitalizada de múltiplos modos de comunicação. Tal sistema tem a capacidade de abarcar e integrar todas as formas de expressão exatamente por causa de sua diversificação, multimodalidade e versatilidade, assim como em razão da diversidade de interesses, valores e imaginações, "inclusive a expressão de conflitos sociais"46.

Assim, a sociedade da informação conectada globalmente além de influenciar a sociabilidade das pessoas tem como característica marcante criar novos contornos em uma democracia pluralista pela interação comunicativa entre os participantes sem a mediação direta e o rígido controle da informação pelo Estado, contribuindo de forma decisiva para o engrandecimento do exercício da liberdade de expressão e manifestação do pensamento dos cidadãos nas democracias contemporâneas.

Como outro vértice desta dimensão global da sociedade da informação e da sua consectária sociedade em rede ${ }^{47}$ Manuel Castells destaca sua importância como instrumento de formação da opinião pública a influenciar os processos de decisão política, vez que o fluxo de comunicação tem o condão de transformar o espaço público ao possibilitar que as pessoas que recebem informação e formem suas convicções. Ele sustenta que uma característica central da sociedade em rede é a transformação da área da comunicação na qual se incluem os meios de comunicação. "A comunicação constitui o espaço

\footnotetext{
${ }^{46}$ CASTELLS, Manuel. A Sociedade em Rede. 6. ed., Tradução Roneide Venacio Majer. São Paulo: Paz e Terra, 1999, p. 460-461.

${ }^{47}$ A sociedade em rede, em termos simples, é uma estrutura social baseada em redes operadas por tecnologias de comunicação e informação fundamentadas na microelectrônica e em redes digitais de computadores que geram, processam e distribuem informação a partir de conhecimento acumulado nos nós dessas redes. A rede é a estrutura formal. Cf. MONGE: CONTRACTOR, 2004. As redes são estruturas abertas que evoluem acrescentando ou removendo nós de acordo com as mudanças necessárias dos programas que conseguem atingir os objetivos de performance para a rede. [...] O que a sociedade em rede é atualmente não pode ser decidido fora da observação empírica da organização social e das práticas que dão corpo à lógica da rede. Disponível em: <http:www.cies.iscte.pt>. Acesso em: 03 set. 2013. CASTELLS, Manuel. Compreender a Transformação Social. p. 17-20. Artigo escrito para Conferência de 4 e 5 de Março de 2005, em Portugal-Lisboa, sobre o título: Sociedade em Rede: do Conhecimento à Acção Política, em Conferência promovida pelo Presidente da República Portuguesa, Jorge Sampaio, organizado por Manuel Castells e Gustavo Cardoso.
} 
público, ou seja, o espaço cognitivo em que as mentes das pessoas recebem informação e formam os seus pontos de vista através do processamento de sinais da sociedade no seu conjunto". Significa dizer que os sistemas de comunicação mediáticos criam relacionamentos entre instituições e organizações da sociedade e das pessoas no seu conjunto não enquanto indivíduos, mas enquanto receptores coletivos de informação, diferentemente da comunicação interpessoal que se trata de uma relação privada, constituída por atores de interação, "[...] mesmo quando a informação final é processada por cada indivíduo de acordo com as suas próprias características pessoais. É por isso que a estrutura e a dinâmica da comunicação social é essencial na formação da consciência e da opinião, e a base do processo de decisão política" ${ }^{48}$.

Assim, a amplitude conferida à liberdade de expressão e de manifestação do pensamento foi potencializada pelos canais de mídia eletrônica ao franquear acesso praticamente ilimitado aos cidadãos para se manifestarem e se informarem mediante interlocução horizontal para debates e troca de opiniões, livre das idiossincrasias e restrições dos demais veículos de massa (TV, Rádio, Jornais), supervisionados pelo Estado. Deste modo, a autonomia gerada pelo acesso a rede digital para a manifestação do pensamento decorre de que os cidadãos têm acesso para selecionar do fluxo de informações que trafega na via digital a comunicação que tem a simpatia de sua personalidade e que é assimilada por cada indivíduo de acordo com as suas próprias características, interesses e escolhas pessoais, a fim de formar a sua opinião. Ao compartilhar ou contestar as ideias veiculadas do espaço virtual, materializa-se a liberdade de expressão e de manifestação do pensamento em sua raiz dialética de conviver com o diferente, de levar em consideração a opinião alheia; Nos dizeres de Celso Lafer "Este direito é uma exigência que deriva da tomada de consciência da irredutibilidade das opiniões e da necessidade de se encontrar um modus vivendi que permita a todos externar suas visões"49.

Por outro vértice, não obstante os benefícios decorrentes da comunicação interativa das redes digitais para o desenvolvimento da liberdade de expressão e de manifestação do pensamento, inegável reconhecer que o franco acesso proporcionado também traz consigo problemas colaterais, conforme aponta Peter T. Night ${ }^{50}$ ao esclarecer que o lado sombrio da internet comporta fins questionáveis como o uso de spam $^{51}$, phishing ${ }^{52}$ etc, e ilegais como o abuso

\footnotetext{
${ }^{48}$ CASTELLS, Manuel. Op. cit., p. 23.

49 LAFER, Celso. Texto de apresentação da obra: A Era dos Direitos, de BOBBIO, Norberto. 13. reimp. Tradução Carlos Nelson Coutinho. Rio de Janeiro: Elsevir Ed., 2004, p. XVII.

${ }^{50}$ KNIGHT, Peter T. Origens, Estratégia, Desenvolvimento e Governança. Prefácio Vint Cerf. São Paulo: Ed. Authorhouse, 2014, p. 99.

${ }^{51}$ Spam é o termo usado para referir-se aos e-mails não solicitados, que geralmente são enviados para um grande número de pessoas. Quando o conteúdo é exclusivamente comercial, esse tipo de mensagem é chamado de UCE (do inglês Unsolicited Commercial E-mail). Disponível em: $<$ www.antispam.br/conceito/>. Acesso em: 09 abr. 2015.

${ }^{52}$ Links para sites que roubam dados, nomes de usuários e senhas de acesso a instituições financeiras e outros tipos de fraude.
} 
infantil, tráfico de drogas, pirataria da propriedade intelectual, invasões de privacidade, terrorismo, espionagem econômica e política de órgãos governamentais e privados, vigilância generalizada, guerra cibernética etc. Como se depreende, se revela extremamente difícil (se não impossível) para Estados e governos conviver com o imenso fluxo de comunicação e conter os abusos, do azo que em decorrência da própria organização em rede as manifestações deletérias (ofensivas, racistas, xenofóbicas, preconceituosas e criminosas) se espraiam (replicadas) de forma instantânea ao redor do mundo sem barreiras de segurança efetiva (firewalls; filtros digitais etc) ${ }^{53}$. Portanto, pela dinâmica da tecnologia em uso a responsabilização dos agentes perpetradores das manifestações em ofensa à lei hoje em dia se revela tarefa hercúlea, já que dificilmente são identificados, principalmente quando sediados no exterior e porque os limites territoriais onde cada estado Estados-nação exerce sua soberania encontra seu limite de atuação na dos demais Estados. Pois, consoante comenta Manuel Castells ${ }^{54}$ : "como não há uma legislação global, embora exista uma rede global de comunicação, a capacidade de controle sistemático e preventivo na prática se dilui" ${ }^{55}$.

\section{LIBERDADE DE EXPRESSÃO E CIDADANIA NA SOCIEDADE DA INFORMAÇÃO}

Gustavo Cardoso comenta com relação às possibilidades que a sociedade da informação por meio da mídia digital contribui para franquear o exercício liberdade de expressão e da livre manifestação de pensamento e opinião e, por corolário, o exercício da cidadania, ao pontuar que Murdock $(1992,1993)$ identifica três formas por meio das quais a mídia pode contribuir para o exercício da cidadania. A primeira oferecendo informação e aconselhando sobre seus próprios direitos. A segunda fornecendo acesso a vasto conjunto de informações, pontos de vista e debates acerca de temas políticos e questões públicas. "Em terceiro, a mídia faculta os meios para que os cidadãos possam expressar críticas e propor soluções alternativas às que Ihes são apresentadas. Por último, na dimensão da experiência, a mídia constitui um referencial de representações, que tanto podem ser assimiladas quanto rejeitadas". Sustenta igualmente, ainda com apoio em Murdock que pode igualmente a mídia operar como instrumento da cidadania porque 0 surgimento da mídia teria permitido a reconfiguração das relações sociais, sustentando que Murdock concedia igualmente à mídia o papel de garantir a cidadania, "no sentido em que não é suficiente dispor de direitos. "Caso não existam as condições básicas para exercer esses direitos é igualmente

\footnotetext{
${ }^{53}$ Resta exemplificado que o custo da fraude bancária online utilizando phishing foi estimado em US\$ 690 milhões, enquanto o custo de limpar computadores infectados e o combate ao crime cibernético (inclusive firewalls, sistemas de detecção de intrusão...), foi estimado em US\$ 20 bilhões. KNIGHT, Peter T. Op. cit., p. 101.

${ }^{54}$ CASTELLS, Manuel. Op. cit., 2003, p. 4. Disponível em: <http://polis.reveus.org/7145\# tocfrom1n1>. Acesso em: 27 mar. 2015.

${ }^{55}$ Ibid.
} 
necessário que existam os recursos simbólicos que permitam denunciar essas situações". Conclui esse seu raciocínio afirmando que a contribuição de maior alcance de Murdock foi no sentido de afirmar que as mídias teriam introduzido nova forma de exercício da cidadania exatamente por permitirem o relacionamento social com pessoas que antes não se conheciam. "É essa característica que permite a organização de indivíduos com objetivos comuns, embora partilhando espaços territoriais diversos" ${ }^{\prime 56}$.

Em seu papel garantidor a mídia e mais ainda as novas mídias digitais peculiares à sociedade da informação permitem a divulgação e esclarecimento de direitos, possibilitam ampliar os debates e manifestação de opiniões, abrem espaço para que os cidadãos possam expressar críticas e soluções, denunciar restrições e permitem, ademais, a organização de imenso contingente de pessoas desconhecidas compartilharem ideias e atuarem para consecução de objetivos comuns. Por outro lado, a utilização destes amplos meios de comunicação e informação pelos poderes instituídos e partidos políticos pode também ser desvirtuada para propaganda ${ }^{57}$, como instrumento de publicidade, renegando direitos de cidadania (nisso incluído a liberdade de se expressar, manifestar livremente opiniões, críticas...) para servir como instrumento de cooptação da vontade do cidadão. Pois, consoante alerta Gustavo Cardoso é o sistema político que modela a mídia que impõe problemas ao exercício da cidadania e não a mídia em si, a televisão ou a internet. Refere-se a Castells que focando a internet afirma que na ocorrência de mobilidade social a internet funciona como dinâmico instrumento para a troca social e que contrariamente onde há burocratização política e política estritamente midiática de representação dos cidadãos a internet é apenas painel de anúncios. "A mídia eletrônica (rádio, televisão, internet) em conjunto com a imprensa constituem o espaço privilegiado da política, da participação e do exercício da cidadania. Um espaço simbólico no qual circula a maior parte da comunicação e informação política produzidas nas democracias". Complementa seu raciocínio pontuando que, no entanto, funcionando como via unidirecional de informação apenas para captar a opinião, "converter simplesmente os cidadãos em votantes potenciais

\footnotetext{
${ }^{56}$ CARDOSO, Gustavo. A Mídia na Sociedade em Rede. Rio de Janeiro: Ed. FGV, 2007, p. 32-33.

57 Jornal Estado de São Paulo, edição de 17/03/2015, matéria sob o título: "Governo cita uso de robôs nas redes sociais em campanha eleitoral". Texto interno da Secretaria da Comunicação Social da Presidência relata que a partir de novembro, 'robôs que atuaram na campanha forma desligados' e diz que expediente ainda é usado no PSDB. O documento reservado de análise da comunicação do governo ao qual o Estado deve acesso admite o uso de robôs para disseminar mensagens pela internet a favor da então candidata à reeleição Dilma Rousseff durante a campanha eleitoral do ano passado. [...] Os chamados robôs são programas que executam com maior velocidade e precisão do que a mão de obra humana diversas tarefas na internet, entre elas replicar mensagens nas redes sociais. Alguns deles têm capacidade de enviar até duas mensagens por segundo via twitter ou facebook. Com isso, infla-se o número de seguidores de uma conta ou de curtidas de uma publicação, o que lhe rende mais destaque nas redes sociais e, consequentemente, alcance maior dos internautas. Disponível em: <http://politica.estadao.com.br/ noticias/geral,governo-cita-uso-de-robos-nas-redes-sociais-em-campanha-eleitoral,1652771>. Acesso em: 17 mar. 2015.
} 
(para que os partidos obtenham informação para saber como ajustar a sua publicidade) perde o seu papel mobilizador e de participação social, de aproximação entre eleitos e eleitores" ${ }^{\prime 58}$.

Nos dias de hoje apenas dispor de acesso ao amplo repertório de mídias (tradicionais e eletrônicas) atualmente existentes e ao amplo fluxo de informações veiculadas nas redes digitais, ínsita à sociedade da informação, não basta para o efetivo exercício de cidadania e da plena liberdade de expressão e opinião. É necessário garantir autonomia e liberdade para se expressar em relação aos poderes instituídos a fim de alimentar a sociedade com informações de fontes confiáveis, complementares e independentes para formar a livre opinião dos cidadãos. Países como China ${ }^{59}$, Turquia, Arabia Saudita, Cuba, Coreia do Norte etc., restringem conteúdos que trafegam pela via digital com o intuito de exercer controle político e censura à liberdade de expressão e manifestação do pensamento e opinião de seus cidadãos dentro de seus domínios soberanos. Além disso, é cediço que Estados ${ }^{60}$ e empresas

\footnotetext{
${ }^{58}$ CASTELLS, Manuel. Op. cit., 1999, p. 322-323.

${ }^{59}$ Artigo da jornalista Paula Sato, sob o título: Em que países a internet não é livre? Às vésperas do $20^{\circ}$ aniversário do Massacre da Praça da Paz Celestial (tragédia ocorrida em 4 de junho de 1989), o governo chinês bloqueou o acesso dos seus 298 milhões de usuários a sites como Twitter, Flickr, Youtube, Wordpress, Blogger, Hotmail e Bing. Até a gigante Microsoft anunciou que entraria em contato com o governo do país para exigir explicações. O fato é que a censura à internet no país não é novidade. Para vigiar o grande número de usuários, o partido comunista gasta bilhões de dólares por ano no controle das informações que circulam pela rede. Manter blogs ou postar vídeos criticando o governo pode acabar em cadeia - tanto é que, segundo o site da ONG Repórteres sem Fronteiras, o país tem a maior prisão do mundo para os considerados criminosos eletrônicos. O governo controla os assuntos proibidos por meio de filtros, que encontram palavras-chave ligadas a movimentos democráticos, como "revolta", "massacre", "direitos humanos" ou "movimento estudantil". Infelizmente, não é só a China que censura o acesso da população à rede. Todos os anos, o Repórteres Sem Fronteiras divulga uma lista de países "inimigos da internet". A última delas, publicada no site da ONG, em 2008, coloca nessa categoria mais 14 países: Arábia Saudita, Belarus, Burma, Cuba, Egito, Etiópia, Irã, Coreia do Norte, Síria, Tunísia, Turcomenistão, Uzbequistão, Vietnã e Zimbábue. Segundo a ONG, "esses países transformaram a internet em uma intranet, impedindo que os usuários obtenham informações consideradas indesejáveis". Além disso, todas essas nações têm em comum governos autoritários, que se mantêm no poder por meio do controle ideológico. Disponível em: <http://revistaescola.abril.com.br/formacao/paisescontrolam-acesso-populacao-internet-474815.shtml>. Acesso em: 09 mar. 2015.

${ }^{60}$ Agencia EFE, 03.02.2015. "EUA anunciam novos limites a programas de coleta de dados. Dados não relevantes de estrangeiros serão eliminados após cinco anos. Em 2013, Snowden revelou que a NSA espionava Merkel e Dilma Rousseff. FACEBOOK. O governo dos Estados Unidos anunciou nesta terça-feira (3) novos limites para o uso de informações sobre americanos e estrangeiros, coletadas através dos programas de espionagem revelados pelo ex-analista da NSA (Agência de Segurança Nacional), Edward Snowden, embora muito mais modestos do que as reformas propostas pelo presidente Barack Obama no ano passado. As novas restrições fazem parte de um relatório divulgado pela Direção Nacional de Inteligência e afetam, fundamentalmente, o uso de dados telefônicos e digitais de cidadãos estrangeiros coletados pela NSA [...]. De acordo com as novas normas, informações de inteligência obtidas pela NSA sobre milhões de cidadãos nos EUA e no exterior só poderão ser usadas para "objetivos específicos": a "caça" de espiões estrangeiros, a luta contra o terrorismo, a cibersegurança, a contenção de ameaças contra o país ou as forças armadas, e o combate a ameaças criminosas internacionais [...]. Por outro lado, o Conselho de Segurança Nacional da Casa Branca exercerá uma maior supervisão sobre a coleta
} 
privadas com know-how praticam espionagem remota de comunicação e informações (e coleta não autorizada de dados pessoais) que trafegam na via digital. Por esse expediente sub-reptício acabam por melindrar o exercício da liberdade de expressão e de manifestação do pensamento dos cidadãos e por consequência o exercício da cidadania; pois, uma vez cônscios da invasão de sua privacidade e de que em alguma extensão são vigiadas as pessoas acabam por não se comunicar livremente sobre temas que eventualmente considerem problemáticos no contexto em que vivem.

Entrementes, ciente de que alguns desdobramentos deletérios decorrem da própria lógica libertária das mídias digitais na sociedade da informação, inegável reconhecer o engrandecimento das possibilidades para o exercício da liberdade de expressão, de manifestação do pensamento e da cidadania, revelando-se como papel do Estado preservar estes valores prioritários para a sociedade e desenvolver abordagens regulatórias ou normativas minimamente invasivas às referidas liberdades, quiçá com o aprimoramento de tecnologias de controle e segurança e de criptografia. Corrobora Manuel Castells ${ }^{61}$ ao confirmar que, na realidade, mais importante do que as tecnologias em defesa da liberdade é a capacidade dos cidadãos se utilizarem das vias digitais para afirmar seu direito a liberdade de expressão e a privacidade nas comunicações; "em última consideração, é na consciência dos cidadãos e na sua capacidade de influência sobre as instituições e através dos meios de comunicação e da própria internet, que reside o fiel da balança entre a rede em liberdade e a liberdade dentro da rede" ${ }^{\text {"62 }}$.

\section{A TOLERÂNCIA COMO MEIO DE RESGUARDAR A LIBERDADE DE EXPRESSÃO E DE MANIFESTAÇÃO DO PENSAMENTO NA SOCIEDADE DA INFORMAÇÃO}

Uma vez consolidado o uso destas tecnologias na sociedade da informação e diante do irreversível desenvolvimento das redes digitais e de sua comunicação interativa para o exercício da liberdade de expressão e da manifestação do pensamento, cabe recordar que embora a internet (infovia) tenha penetração mundial, os homens vivem em sociedades regionais (ou locais) e cuja cultura e valores são próprios e têm formas diferentes de interpretar o que é ou não permitido. Assim, classificar previamente conteúdos proibitivos ou estabelecer "filtros" que impeçam acesso e propagação de manifestação tida por deletéria nas redes ainda que a título de proteger a sociedade tendem a transbordar para a censura e eventual arbitrariedade para excluir pontos de vistas minoritários.

\footnotetext{
da inteligência no exterior por parte da NSA. Ao mencionar a persistência de ameaças terroristas e dos ciberataques, a principal assessora em matéria antiterrorista de Obama, Lisa Monaco, ressaltou que os Estados Unidos devem usar suas capacidades de inteligência para proteger a segurança nacional e, ao mesmo tempo, garantir "o respeito à privacidade e às liberdades civis". Disponível em: <http://g1.globo.com/mundo/noticia/2015/02/eua-anunciam-novos-limites-programasde-coleta-de-dados.html>. Acesso em: 16 mar. 2015.

${ }^{61}$ CASTELLS, Manuel. Op. cit., 2003, p. 6.

${ }^{62}$ Ibid.
} 
Qualquer intervenção do Estado e Governos nas vias digitais deve ser cautelosa a fim de não tolher o desenvolvimento da liberdade de expressão e da livre manifestação do pensamento, elementos indispensáveis à reflexão da sociedade. Tem a informar Gustavo $\operatorname{Cardoso}^{63}$ que, ao analisar a atuação de diversos Estados na via digital constata-se que existem duas tendências políticas sobre como lidar com os conteúdos veiculados on line: a forma reguladora e a libertária. A reguladora tem por escopo produzir legislação para combater crimes (Ex. a pornografia na rede) e proteger menores através da utilização de filtros que restrinjam acesso a conteúdos. E as posições libertárias, baseadas no reconhecimento das características da própria internet (limitada capacidade de controlar conteúdos; amplitude da liberdade de comunicação), que defendem que o controle recaia sobre os usuários, cabendo ao Estado concentrar esforços para atuar após o surgimento de conteúdos deletérios e não através da censura prévia de conteúdos, a fim de evitar ameaças à liberdade de expressão ${ }^{64}$.

Diante desse dilema e em defesa da posição libertária de priorizar a atuação estatal repressiva parece-nos que o elemento que permite estabelecer uma linha de atuação entre as demais liberdades que podem entrar em conflito, principalmente na sociedade da informação e suas mídias sociais reside em cultivar a tolerância com relação aos conteúdos e manifestações com as quais não compartilhamos e ter grandeza para aceitar eventuais admoestações advindas de sátira e caricaturas humorísticas; refletir que somente mediante processo educativo pode-se derrubar preconceitos e educar cidadãos a respeitar religiões, culturas, etnias e personalidades diversas. É importante levar em consideração uma obviedade: se nós cidadãos fossemos todos de uma só religião, mesma raça, cultura e igual visão de mundo a exigência da liberdade de expressão e de livre manifestação do pensamento não faria qualquer sentido prático ou jurídico.

Ademais, em decorrência do processo civilizatório que vivenciamos e que ficou conhecido por Globalização ${ }^{65}$ e do qual a sociedade da informação ${ }^{66}$

\footnotetext{
${ }^{63}$ CARDOSO, Gustavo. As Causas das Questões ou o Estado à Beira da Sociedade da Informação. Sociologia - Problemas e Práticas, no 30, 1999, p. 122-123. Disponível em: <http://bocc.ubi.pt/ pag/cardoso-gustavo-causas-questoes.html>. Acesso em: 10 abr. 2015.

${ }_{64}$ Ibid.

${ }^{65}$ A globalização é um dos processos de aprofundamento internacional da integração econômica, social, cultural, política, que teria sido impulsionado pelo barateamento dos meios de transporte e comunicação dos países no final do século $X X$ e início do século XXI. Disponível em: <http://pt.wikipedia.org/wiki/Globaliza\%C3\%A7\%C3\%A3o>. Acesso em: 10 mar. 2015.

${ }^{66}$ Graças à revolução tecnológica no custo e na velocidade dos transportes e comunicações, os emigrantes de longo prazo, do século XXI, ao contrário do século XX, já não estão efetivamente separados das suas comunidades de origem, como antes estavam, a não ser por cartas, visitas ocasionais ou, no máximo, através do 'nacionalismo de longa distância', das organizações de emigrantes que financiavam organismos políticos dos seus países de nascimento. Prósperos emigrantes, hoje, circulam entre suas casas, ou mesmo seus trabalhos e negócios, no país antigo e no novo. Os aeroportos da América do Norte ficam inundados nos feriados por centro-americanos que se dirigem a alguma cidadezinha de El Salvador ou da Guatemala, levando presentes eletrônicos.
} 
é tributária direta, com a integração das economias, do sistema financeiro, dos mercados de trabalho, da comunicação e da ampla circulação de pessoas entre países, é natural que ocorram conflitos atinentes à liberdade de expressão e de manifestação do pensamento entre cidadãos com etnia, origem, religião, condição social e cultural diferentes. Nesse sentido, temos que enaltecer os propósitos da Conferência Geral da UNESCO, em sua $28^{\mathrm{a}}$ Reunião, sediada em Paris, em 16 de Novembro de 1995, a qual aprovou a Declaração de Princípios sobre a Tolerância ${ }^{67}$, esclarecendo respectivamente seu (i) significado ${ }^{68}$, (ii) o papel do Estado ${ }^{69}$, (iii) suas dimensões sociais ${ }^{70}$, e (iv) 0 papel da educação ${ }^{71}$ na sua consolidação.

Em linhas gerais pode-se dizer que pelas quatro dimensões abordadas em referida Declaração de Princípios da UNESCO deliberou-se, respectivamente para: (i) conceituar a tolerância como um ato de respeito e apreço à diversidade cultural humana, fomentada pela abertura de espírito, pela liberdade de comunicação, de pensamento, de consciência e crença; (ii) que na esfera de atuação do Estado, a tolerância se desdobra em exigir justiça e imparcialidade na legislação e aplicação da lei e no exercício dos poderes judiciário e executivo, com a promoção de oportunidades para todos sem qualquer discriminação;

As festas familiares em um país são - o antigo ou o novo - são frequentadas por amigos e parentes de três continentes. HOBSBAWM, Eric. Globalização, Democracia e Terrorismo. Tradução José Viegas. São Paulo: Companhia das Letras, 2007, p. 90.

${ }^{67}$ Disponível em: <http://www.dhnet.org.br/direitos/sip/onu/paz/dec95.htm>. Acesso em: 13 mar. 2015.

${ }^{60}$ Artigo $1^{\circ}$ - Significado da tolerância

1.1 A tolerância é o respeito, a aceitação e o apreço da riqueza e da diversidade das culturas de nosso mundo, de nossos modos de expressão e de nossas maneiras de exprimir nossa qualidade de seres humanos. É fomentada pelo conhecimento, a abertura de espírito, a comunicação e a liberdade de pensamento, de consciência e de crença. A tolerância é a harmonia na diferença. Não só é um dever de ordem ética; é igualmente uma necessidade política e jurídica. A tolerância é uma virtude que torna a paz possível e contribui para substituir uma cultura de guerra por uma cultura de paz. Ibid., Conferência Geral da UNESCO, em sua 28ª Reunião, Paris, 1995.

${ }^{69}$ Artigo $2^{\circ}-O$ papel do Estado

2.1 No âmbito do Estado, a tolerância exige justiça e imparcialidade na legislação, na aplicação da lei e no exercício dos poderes judiciário e administrativo. Exige também que todos possam desfrutar de oportunidades econômicas e sociais sem nenhuma discriminação. A exclusão e a marginalização podem conduzir à frustração, à hostilidade e ao fanatismo. Ibid.

${ }^{70}$ Artigo $3^{\circ}$ - Dimensões sociais

3.1 No mundo moderno, a tolerância é mais necessária do que nunca. Vivemos uma época marcada pela mundialização da economia e pela aceleração da mobilidade, da comunicação, da integração e da interdependência, das migrações e dos deslocamentos de populações, da urbanização e da transformação das formas de organização social. Visto que inexiste uma única parte do mundo que não seja caracterizada pela diversidade, a intensificação da intolerância e dos confrontos constitui ameaça potencial para cada região. Não se trata de ameaça limitada a esse ou aquele país, mas de ameaça universal. Ibid.

${ }^{71}$ Artigo $4^{\circ}$ - Educação

4.1 A educação é o meio mais eficaz de prevenir a intolerância. A primeira etapa da educação para a tolerância consiste em ensinar aos indivíduos quais são seus direitos e suas liberdades a fim de assegurar seu respeito e de incentivar a vontade de proteger os direitos e liberdades dos outros. Ibid. 
(iii) no âmbito social, reconhecer que na sociedade contemporânea a tolerância se faz indispensável exatamente em decorrência da integração e interdependência dos povos, trazendo consigo a globalização econômica, comunicativa e de mobilidade das pessoas; ao derradeiro, (iv) pela dimensão educacional estabelecer que o processo educativo é meio eficaz para prevenir a intolerância, ensinando aos cidadãos seus direitos e liberdades e que estes devem ser exercidos consentâneo aos direitos das demais pessoas.

Incumbe ressaltar que aos Estados-membros integrantes da UNESCO, como o Brasil, cabe desenvolver e fomentar o respeito dos direitos humanos e das liberdades fundamentais de todos, sem distinção fundada sobre a raça, o sexo, a língua, a origem nacional, a religião ou incapacidade e combater a intolerância. E que todas as considerações albergadas acima ressaltando a importância da tolerância para o tempo que vivemos igualmente se aplicam ao ambiente telemático. Norberto Bobbio ${ }^{72}$ esclarece os nuances do entendimento prático ou de prudência política da tolerância, sem abrir mão de suas convicções, no contexto de correlação de forças antagônicas numa sociedade multifacetada. Para o Autor, se nos considerarmos iguais aos demais passa a valer o princípio da reciprocidade das relações e sobre qual se sustentam todos os compromissos e acordos sociais que permitem uma convivência pacífica. Neste caso a tolerância opera como uma troca: "sob a égide do se tu me toleras, eu te tolero"73; por outro lado, se promovo a perseguição de outrem parece evidente que com a mudança das circunstâncias este outrem me devolverá na mesma moeda persecutória. Assim, a tolerância envolve de forma consciente e utilitária o resultado de uma análise de custo/benefício pelas partes independentemente da fé ou razão factual.

Complementarmente, outra razão para valorizar a tolerância e enaltecer a liberdade de expressão e de manifestação do pensamento, principalmente na sociedade da informação, está em adotá-los como método de convivência civil, conforme aduz Norberto Bobbio ${ }^{74}$. Por esse enfoque a tolerância passa a ser compreendida como uma atitude de altivez e de recusa à violência, confiando na razão humana e na razoabilidade de todos que pensam diferente, no sentido de que ao seu tempo a verdade virá à tona e prevalecerá. Além das razões de ordem prática Norberto Bobbio ${ }^{75}$ milita em favor da tolerância ainda como uma condição moral; o de respeitar a pessoa alheia, o compromisso da benevolência em face do outro, pois o reconhecimento do direito do homem a crer de acordo com sua consciência tem relação direta à afirmação dos direitos de liberdade e dos demais consectários como da liberdade religiosa, liberdade de opinião, de informação etc., enquanto elementos estruturantes do Estado liberal democrático.

\footnotetext{
72 BOBBIO, Norberto. A Era dos Direitos. Tradução Carlos Nelson Coutinho. Rio de Janeiro: Ed. Elsevier, 2004, p. 186-189.

${ }^{73}$ Ibid., p. 189.

${ }^{74}$ Ibid., p. 190.

${ }^{75}$ Ibid., p. 191.
} 
Norberto Bobbio ressalta a faceta da tolerância enquanto elemento ético ao pontuar que o cidadão deve ter primeiramente sua fundamental liberdade interior respeitada; direito a formar seu convencimento por escolha própria e não pela coação de quem quer que seja. Portanto, como imperativo de uma sociedade da informação plural e democrática onde o cultivo das liberdades é um paradigma, a tolerância opera também como princípio de integração para respeitar a consciência interior daquele que pensa diferente de nós, em deferência à sua condição humana. Em decorrência da premissa anterior, referido autor ${ }^{76}$ conclui que a tolerância opera como método dialético para se chegar à verdade vez que esta só pode ser alcançada através do confronto de ideias, pois: "Segundo tais doutrinas, a verdade não é una. A verdade tem muitas faces. Vivemos não num universo, mas num multiverso. Num multiverso, a tolerância não é apenas um método de convivência, não é apenas um dever moral, mas uma necessidade inerente à própria natureza da verdade" ${ }^{\prime 77}$.

Em que pesem tais argumentos, temos que as variedades de manifestação do pensamento e seus desdobramentos se constituem na maior riqueza do processo cultural e civilizatório da humanidade revelando-se contraproducente uma limitação das liberdades de expressão mediante proibições de conteúdos ou de acesso nas redes digitais. E como aduz Norberto Bobbio a perseguição não é a melhor maneira de fazer o intolerante aceitar a tolerância, mas, ao contrário, reconhecer o seu direito de se expressar. "É melhor uma liberdade sempre em perigo, mas expansiva, do que uma liberdade protegida, mas incapaz de se desenvolver. Somente uma liberdade em perigo é capaz de se renovar. Uma liberdade incapaz de se renovar transforma-se, mais cedo ou mais tarde, numa nova escravidão"78.

Ao procurar restringir essas liberdades na sociedade da informação estar-se-á apequenando um horizonte holístico de construção de verdades parciais e suas inter-relações ao impedir a renovação dialética de conceitos e visões de mundo que com o tempo vai se modificando conforme a humanidade trilha seu caminho. E porque o desenvolvimento da criatividade humana em suas múltiplas facetas e concreções (intelectuais, artísticas, científicas, e de comunicação, bem como espirituais que vicejam no Ser ...) tem relação de dependência com ampla liberdade de se expressar e de manifestar o pensamento e opinião para a construção da identidade das pessoas; enfim, "a tolerância é uma virtude que torna a paz possível e contribui para substituir uma cultura de guerra por uma cultura de paz" ${ }^{\prime 79}$.

\footnotetext{
${ }^{76}$ BOBBIO, Norberto. Op. cit., p. 192.

77 lbid.

${ }^{78}$ Ibid., p. 196-197.

${ }^{79}$ Conferência Geral da UNESCO, em sua $28^{a}$ Reunião, sediada em Paris, 16 de novembro de 1995, a qual aprovou a Declaração de Princípios sobre a Tolerância., artigo $1^{\circ}$, parte final "item 1.1".
} 


\section{CONCLUSÃO}

As liberdades de expressão e de manifestação do pensamento e opinião são classificadas pela doutrina como negativas, pois exigem que o Governo se abstenha como regra de limitar as intervenções sociais que compõem a personalidade humana; têm por escopo conferir o livre-arbítrio aos cidadãos de fazer suas escolhas e de se manifestar livremente.

A liberdade de expressão (e seus desdobramentos) e a de manifestação do pensamento se assentam em contornos amplos numa sociedade pluralista e visam garantir a tutela de outros direitos fundamentais que envolvam a comunicação de opiniões, crítica, debates, convicções, comentários ou julgamento sobre qualquer assunto ou pessoa, envolvendo interesse público ou não, servindo como meio de preservação do processo democrático na sociedade da informação.

Pode-se dizer em linhas gerais que a liberdade de expressão e de manifestação do pensamento encontra seus limites para proibir o anonimato, para impor direito de resposta, indenizar por danos morais e patrimoniais e à imagem causados, para preservar a intimidade, a vida privada, a honra e a imagem das pessoas e para assegurar a todos o direito de acesso à informação; e que outros valores constitucionais podem entrar em conflito com a liberdade de expressão, exigindo-se conforme o caso concreto a ponderação entre os valores fundamentais envolvidos e decidir qual princípio deverá preponderar.

Embora os dispositivos que cuidam do tema sejam enfáticos em obstar qualquer censura ou exigir licença para se exercer a liberdade de manifestação, a interpretação sistemática constitucional autoriza ao Judiciário dar guarida à proteção preventiva em caso de outro princípio fundamental estar na iminência de ser maculado, em respeito à garantia da efetiva proteção jurisdicional.

As redes digitais (internet) têm penetração mundial, embora os homens vivam em sociedades regionais (ou locais), imersos em cultura, valores e legislação própria. Como não há uma legislação global, embora exista uma rede global de comunicação a capacidade de controle e regulação normativa pelos Estados com relação ao exercício da liberdade de expressão e de manifestação do pensamento nas redes se torna bastante difícil, pois cada Estados-nação que exerce sua soberania encontra limite de atuação na dos demais Estados.

Estabelecer mediante regulação normativa conteúdos proibitivos nas redes digitais que impeçam a liberdade de expressão e a livre propagação de ideias, ainda que a título de proteger a sociedade, poderá transbordar para a censura e eventual arbitrariedade para excluir pontos de vistas minoritários.

A sociedade da informação conectada globalmente pela rede mundial de computadores (Internet), além de influenciar a sociabilidade das pessoas tem como característica marcante criar novos contornos sociais pela interação comunicativa entre participantes sem a mediação direta e controle da informação pelo Estado, contribuindo de forma decisiva para o engrandecimento do 
exercício da liberdade de expressão e manifestação do pensamento (por corolário, na formação da opinião pública) dos cidadãos nas democracias contemporâneas.

Especialmente no âmbito cibernético a liberdade de expressão e a de manifestação do pensamento não se constitui apenas como direito fundamental, mas também, como condição de possibilidade para a defesa e desenvolvimento dos demais direitos fundamentais. E como imperativo de uma sociedade democrática onde o cultivo das liberdades é um paradigma, a tolerância opera além de método de convivência como princípio de integração para respeitar a consciência interior do que pensa diferente, revelando-se um dever de ordem ética e igualmente uma necessidade política e jurídica.

\section{REFERÊNCIAS}

ALEXY, Robert. Teoria dos Direitos Fundamentais. 2. ed., Tradução Virgílio Afonso da Silva. São Paulo: Malheiros, 2014.

ARENDT, Hannah. A Condição Humana. 11. ed., Rio de Janeiro: Forense Universitária, 2010.

ARISTÓTELES. A Política. 1. ed., Tradução Nestor Silveira. São Paulo: Folha de São Paulo, 2010.

BASTOS. Celso Ribeiro. Curso de Direito Constitucional. São Paulo: Celso Bastos Editora, 2002.

BOBBIO, Norberto. A Era dos Direitos. 13. reimp. Tradução Carlos Nelson Coutinho; Apresentação Celso Lafer. Rio de Janeiro: Elsevier, 2004.

BRANCO, Paulo Gustavo Gonet; MENDES, Gilmar Ferreira. Curso de Direito Constitucional. 8. ed., ver. atual. São Paulo: Saraiva, 2013.

BRASIL. Constituição da República Federativa do Brasil 1988. 19. ed., Brasília: Câmara dos Deputados, Centro de Documentação e Informação Coordenação de Publicações, 2002.

BULOS, Uadi Lammêgo. Direito Constitucional ao Alcance de Todos. 3. ed., São Paulo: Ed. Saraiva, 2011.

CANOTILHO. J. J. Gomes. Direito Constitucional e Teoria da Constituição. 6. ed., Coimbra: Almedina, 2002.

CARDOSO, Gustavo. A Mídia na Sociedade em Rede. Rio de Janeiro: FGV, 2007.

As Causas das Questões ou o Estado à Beira da Sociedade da Informação.

Sociologia - Problemas e Práticas, no 30, 1999.

CASTELLS, Manuel. A Sociedade em Rede. 6. ed., v. 1, Tradução Roneide Venacio Majer. São Paulo: Paz e Terra, 1999.

Comentário Contextual à Constituição. 5. ed., São Paulo: Malheiros, 2007.

Compreender a Transformação Social. Artigo escrito para Conferência de $4 \mathrm{e}$

5 de Março de 2005, em Portugal-Lisboa, sobre o título: Sociedade em Rede: do Conhecimento à Acção Política, em Conferência promovida pelo Presidente da República Portuguesa, Jorge Sampaio, organizado por Manuel Castells e Gustavo Cardoso.

. Internet, Libertad y Sociedad: una perspectiva analítica. Polis, Revista Latinoamericana, $\mathrm{n}^{\circ}$ 4, 2003. 
HOBSBAWM, Eric. Globalização, Democracia e Terrorismo. Tradução José Viegas. São Paulo: Companhia das Letras, 2007.

KNIGHT, Peter T. Origens, Estratégia, Desenvolvimento e Governança. Prefácio Vint Cerf. São Paulo: Ed. Authorhouse, 2014.

LAFER, Celso. Texto de Apresentação p. XVII, da obra: A Era dos Direitos de Norberto Bobbio. 13. ed., Tradução de Carlos Nelson Coutinho. Rio de Janeiro: Elsevir Ed., 2004.

MCEWAN, Ian. Liberdade de Expressão. Tradução Clara Allain, São Paulo, Jornal Folha de São Paulo, Tendências/Debates, edição de 2 de Janeiro de 2015.

MENDES, Gilmar Ferreira. Direitos Fundamentais e Controle de Constitucionalidade. São Paulo: Celso Bastos Editor, 1998.

SILVA, José Afonso da. Curso de Direito Constitucional Positivo. 9. ed., São Paulo: Malheiros, 1994.

\section{Referências bibliográficas digitais: Disponíveis em:}

$<$ http://www.embaixada-americana.org.br/democracia/speech.htm>. Acesso em: 15 fev. 2015.

<http://www.cies.iscte.pt>. Acesso em: 03 set. 2013.

$<$ http://www.dn.pt/inicio/globo/interior.aspx?content_id=4327721>. Acesso em: 09 mar. 2015.

<http://leonardoboff.wordpress.com/2015/01/10/eu-nao-sou-charlie-je-ne-suis-pas-charlie/>. Acesso em: 10 mar. 2015.

<http://passapalavra.info/2015/01/101964>. Acesso em: 05 mar. 2015.

$<$ http://revistaescola.abril.com.br/formacao/paises-controlam-acesso-populacao-internet474815.shtml>. Acesso em: 09 mar. 2015.

<http://pt.wikipedia.org/wiki/Globaliza\%C3\%A7\%C3\%A3o>. Acesso em: 10 mar. 2015. <http://www.dhnet.org.br/direitos/sip/onu/paz/dec95.htm>. Acesso em: 13 mar. 2015. $<$ http://g1.globo.com/mundo/noticia/2015/02/eua-anunciam-novos-limites-programas-decoleta-de-dados.html>. Acesso em: 16 mar. 2015.

<http://pensador.uol.com.br/posso_nao_concordar_com_o_que_dizes>. Acesso em: 25 mar. 2015.

<http://windows.microsoft.com/pt-pt/windows/what-is-encryption\#1TC=windows-7>. Acesso em: 06 abr. 2015.

<http://polis.reveus.org/7145\#tocfrom1n1>. Acesso em: 27 mar. 2015. 